\title{
Redistributive Public Employment
}

\section{Citation}

Alesina, Alberto, Reza Baqir, and William Easterly. 2000. Redistributive public employment. Journal of Urban Economics 48(2): 219-241.

\section{Published Version}

doi:10.1006/juec.1999.2164

\section{Permanent link}

http://nrs.harvard.edu/urn-3:HUL.InstRepos:4553013

\section{Terms of Use}

This article was downloaded from Harvard University's DASH repository, and is made available under the terms and conditions applicable to Other Posted Material, as set forth at http:// nrs.harvard.edu/urn-3:HUL.InstRepos:dash.current.terms-of-use\#LAA

\section{Share Your Story}

The Harvard community has made this article openly available.

Please share how this access benefits you. Submit a story.

Accessibility 


\title{
NBER WORKING PAPER SERIES
}

\section{REDISTRIBUTIVE \\ PUBLIC EMPLOYMENT}

\author{
Alberto Alesina \\ Reza Baqir \\ William Easterly
}

Working Paper 6746

http://www.nber.org/papers/w6746

\author{
NATIONAL BUREAU OF ECONOMIC RESEARCH \\ 1050 Massachusetts Avenue \\ Cambridge, MA 02138 \\ October 1998
}

We thank Roberto Perotti for several conversations, and Jakob Svensson for useful comments on a preliminary draft. Alberto Alesina gratefully acknowledges financial support from an NSF grant. The views expressed here are those of the authors and do not reflect those of the National Bureau of Economic Research, the World Bank, or its member countries.

(C) 1998 by Alberto Alesina, Reza Baqir, and William Easterly. All rights reserved. Short sections of text, not to exceed two paragraphs, may be quoted without explicit permission provided that full credit, including $\mathbb{C}$ notice, is given to the source. 
Redistributive Public Employment

Alberto Alesina, Reza Baqir, and William Easterly

NBER Working Paper No. 6746

October 1998

\begin{abstract}
Politicians may use "disguised" redistributive policies in order to circumvent opposition to explicit tax-transfer schemes. First, we present a theoretical model that formalizes this hypothesis; then we provide evidence that in US cities, politicians use public employment as such a redistributive device. We find that city employment is significantly higher in cities where income inequality and ethnic fragmentation are higher.
\end{abstract}

Alberto Alesina

Department of Economics

Harvard University

Cambridge, MA 02138

and NBER

aalesina@harvard.edu
Reza Baqir

Department of Economics

549 Evans Hall \#3880

University of California, Berkeley

Berkeley, CA 94720-3880

bazir@econ.berkeley.edu

William Easterly

The World Bank

N-11-043

1818 H Street, NW

Washington, DC 20433

weasterly@worldbank.org 


\section{Introduction}

We argue that in American cities public employment is used for redistributive purposes. Its level is not chosen only from the point of view of "productive efficiency" but as a way of directing income toward disadvantaged groups, and for politically privileged groups.

Why would politicians use this indirect and probably inefficient method to redistribute income? The answer is that public projects are often a disguised way of channeling resources from middle class voters to disadvantaged citizens when an explicit transfer scheme would not find political support. Under certain conditions of asymmetric information, prititicians can claim that public projects are needed for efficiency, even though they really are redistributive tools. Therefore, while an explicit and more efficient redistributive scheme would be politically opposed, a less efficient system based upon inflated government bureaucracies may find political support.

Local and international examples of bloated public employment abound. In highly unequal and ethnically fragmented Washington DC in 1992, 1 out of every 13 residents was a city employee. In highly unequal and ethnically fragmented Kenya in the 90 s, civil servants employed by 21 separate cabinet ministries and at least 93 separate government ent:sprises made up about half of all formal wage employment. ${ }^{1}$ In Italy, there are more forest rangers in a small mountainous region of the poor south than in the entire Italian section cif the Alps. More generally, public employment is one of the main channels of redistribution from rich to poor regions in Italy. In this paper we document that there is something systematic about this use of government employment as a redistributive device and as a patronage mechanism. As a theoretical

${ }^{1}$ Sources are Grosh (1991) p. 12; Miller and Yeager (1994), World Government Directory for number of ministries, and World Bank data on public and private wage employment. 
underpinning we use a model by Coate and Morris (1995). ${ }^{2}$ Their emphe is is different from ours, but we can adapt their model to capture the hypothesis that we then test.

Our empirical results on American cities are strong. We show that, after controlling for several other determinants of city employment, a more unequal income uistribution is associated with larger public employment. This result holds regardless of the measure of income inequality, including the Gini coefficient, mean to median ratios of households income, and poverty ratios. Also, we find that more ethnically fragmented cities tend to have larger public employment, suggesting that the latter may be used as an implicit subsidy to ethnically defined interest groups This second result is consistent with our findings on public spending as a function of ethnic fragmentation in US cities discussed in Alesina, Baqir and Easterly (1996).

The present paper also has implications for the literature on income inequality and redistributions, initiated by Meltzer and Richards (1981). ${ }^{3}$ According to that paper, more inequality measured by a lower ratio of median to mean income would lead the decisive median voter to require larger transfers financed by an income tax. However, the empirical evidence on this mechanism has been inconclusive at best, as discussed by Perotti (1996) and Rodriguez (1997a), in cross country samples and samples of US states respectively. In particular, Rodriguez (1997b) argues that the wealthy can "block" explicit redistributive policies by virtue of the larger resources that they can use for lobbying activities. As a result, more inequality does not necessarily lead to more explicit redistributive polices. Our findings suggest that one of the

${ }^{2}$ Similar ideas were discussed informally in Tullock $(1983,1989)$. context.

${ }^{3}$ Alesina and Rodrik (1994) and Persson and Tabellini (1994) ariply this model to a growth 
reasons why it is difficult to find evidence of a relationship between pre tax inequality and redistributive policies, is that the latter may take several disguised forms. Some programs are not redistributive per se but are used as an indirect form of redistribution, precisely to circumvent the opposition of those who would have to finance the explicit redistributive programs.

The paper is organized as follows. Section 2 discusses a version of the Coate and Morris (1995) model which serves as a motivation for our empirical analysis. Section 3 presents our data and simple correlations. Sections 4 and 5 discusses our results. The last section concludes.

\section{The Model}

We slightly modify a model by Coate and Morris (1995) to fit our empirical interests. ${ }^{4}$ Consider a political jurisdiction, which we call "city," with an eye on the empirical work of the next sections. In this two period model, voters have to decide whether or not to reelect the incumbent at the end of the first period. There are two groups of voters in the city. One group which we label the "majority" and another group, which we call the "minority". We can interpret these two groups as, say, the upper and middle class (the majority) and a group of disadvantaged citizens, in terms of income and/or race, perhaps living in the inner city. Nobody can win elections without the support of the majority; thus, no politicians can afford to alienate this group of voters, if he wants to be reelected.

The incumbent politician has to decide whether and how much to transfer from the majority to the minority. This redistribution of income can take a direct form, that is a cash

${ }^{4}$ This agency type model of political competitions is related to work by Barro (1973), Ferejohn (1986) and Austen-Smith and Banks (1989). 
transfer financed by a tax on income, or an indirect form. The "indirect" form is available since the minority can receive an income boost from a public project which requires public employment The representative member of the majority has the following utility function (the subscript $\mathrm{M}$ stands for "majority"):

$$
u_{M}=y_{M}-t+B
$$

where $\mathrm{t}$ are taxes, $\mathrm{B}$ are the benefits from the public project and $y_{M}$ is the exogenously given income. The representative member of the minority has a linear utility equal to (the subscript $\mathrm{m}$ stands for "minority"):

$$
u_{m}=R+T
$$

where $\mathrm{T}$ is a direct cash transfer and $\mathrm{R}$ is the income level derived by the project requiring public employment. Thus we can think that $R=p w$, where $w$ is the pubiic wige income and $p$ is the exogenously given probability that a particular member of the minority is chosen as a public employee. This public project could be, for instance, a new bridge which, in order to be built needs employment from the minority, but produces benefits to the majority. For simplicity of exposition, we impose the restriction that all the benefits of the projects for the minority come from an increase in income due to the larger employment. The model could be easily extended to the case in which the project also brings about some benefit for the minority. In the bridge example this amounts to saying that members of the minority also use the bridge, in addition to being employed for building it.

When in office in the first period the politician can also choose to make a cash transfer 
$T \geq 0$, financed with taxes on the majority, in addition to choosing whether or not to engage in the public project. There is uncertainty aboui the output of the project; with probability $\theta$ the project generates high benefits $\left(B_{H}\right)$ and with probability $(1-\theta)$ the project generates low benefits $\left(B_{L}\right)$, with $B_{H}>B_{L}>0$. The probability $\theta$ can assume two values, a low one $\left(\theta_{L}\right)$ or a high one, $\left(\theta_{H}\right)$, with $\theta_{L}<\theta_{H}$. The politicians, but not the voters observe $\theta$ before having to decide whether to implement the project or not. The expected gain for the majority, $\bar{B}(\theta)$ is equal to:

$$
\bar{B}(\theta)=\theta B_{H}+(1-\theta) B_{L}-t
$$

Assume that:
A1. I)$$
\bar{B}\left(\theta_{H}\right)>0
$$
ii)$$
\bar{B}\left(\theta_{L}\right)<-R
$$

Thus, (4a) states that when $\theta=\theta_{H}$ the project yields positive net expected benefits to the majority. Equation (4b) states that if $\theta=\theta_{L}$ the project yields negative expected benefits to the majority; (4b) also implies that, with perfect information, the latter would prefer to be taxed to finance a direct cash transfer to the minority, rather than implementing the project.

There are two types of politicians, one favorable to the "majority" $(I=M)$, and one to the "minority" $(\mathrm{I}=\mathrm{m})$. When politicians are not in office they receive zero utility. When in office the utility function of the $\mathrm{M}$ politician is: 


$$
V_{M}=V_{M}\left(u_{M}-y_{M}\right)
$$

where $V_{M}(\cdot)$ is a smooth increasing function, and $V_{M}(0)>0$. That is, even when the politician fails to generate utility beyond $y_{M}$ to the majority, he still prefers being in office rather than out. Analogously, the utility level for a minority politician is given by

$$
V_{m}=V_{m}\left(u_{M}-y_{M}, y_{m}\right)
$$

with $V_{m}(0,0)>0$. We also assume that the type ' $m$ ' politician prefers to introduce the project even when $\theta=\theta_{L}$. Note that equation (6) implies that the "minority" politician cares a bit also about the majority. This is not so important, but the critical assumption is that even when it generates zero utility for the minority, the ' $\mathrm{m}$ ' politician prefers being in office rather than out.

The voters do not know whether the incumbent is the "M" type or the "m" type. Since only with the support of the majority can an incumbent win the election . he 'minority' politician has an incentive to disguise himself as a 'majority' type. Thus, simple announcements about types would be irrelevant 'cheap talk'. Voters have priors about politicians: $\lambda_{M}$ is the prior probability that the incumbent is of type $M ; \lambda_{M}^{C}$ is the prior probability that the challenger is of type $M$ $\lambda_{M}^{C}$ is drawn from a cumulative distribution $G\left(\lambda_{M}^{C}\right)$. The incumbent knows $\lambda_{M}^{I}$.

Note that in the context of American cities, whether the mayor is a Democrat or a Republican may convey some information about his preferences. This iniplies that depending

${ }^{5}$ This model of politicians' behavior is an hybrid between a pure 'partisan' model where the parties care only about their ideology, and an 'opportunistic' model where they only care about winning. For an overview of these issues, see Alesina and Rosenthal (1995), Ch. 2. 
upon whether the incumbent is a Democrat or a Republican, $\lambda_{M}^{C}$ and $\left.\lambda_{M}\right)$ may be different. However, the voters still maintain some uncertainty about the nature of the particular incumbent and challenger, even if they know their party affiliation. Also, as pointed out before, the incentive structure is such that no politicians would claim to be of type "m", thus no politician can credibly claim to be of type " $\mathrm{M}$ '.

Under a reasonable assumption about the evolution of voters' beliefs, ${ }^{6}$ Morris and Coate (1995) establish the following

RESULT: There exists a $\lambda^{*} \in(0,1)$ such that a ' $m$ ' type incumoent always chooses to implement the project, and makes no direct transfers $(\mathrm{T}=0)$, if $\lambda_{M}^{I}>\lambda^{*}$. A type "M" incumbent implements the project only if $\theta=\theta_{H}$.

PROOF: Proposition 2 of Coate and Morris $(1995)^{7}$

In words, the idea is that for certain parameter values, the ' $m$ ' politician would choose to increase public employment even when this is inefficient, i.e., $\theta=\theta_{L}$. The reason is that if the ' $m$ ' incumbent would choose explicit cash transfers when they are efficient (i.e., $\theta=\theta_{L}$ ) he would reveal himself and loose the election. If $\lambda_{M}^{J}$ is high, then the $\mathrm{m}$ type incumbent has a relatively good chance of winning. Therefore, the type " $\mathrm{m}$ " incumbent has a strong incentive not to reveal himself. If he reveals himself he can follow more efficient policies in the first period. However, by revealing himself he is certain to lose the election, giving away a good chance of being in office tomorrow. Being in office tomorrow increases his utility for two reasons: he can

${ }^{6}$ The assumption is of "monotonic beliefs". Informally, the assumption states that given a pair of transfers $T^{\prime}$ and $T$ chosen in the first period, of $T^{\prime}>T$ than the ex post probability that the incumbent is of $M$ type ( $\alpha^{\prime}$ and $\alpha$ ) is such that $\alpha^{\prime} \leq \alpha$.

${ }^{7}$ With an additional innocuous assumption these authors also establish uniqueness. 
implement the most desired policies and enjoy the benefits of office holding. Thus, if $\lambda_{M}^{I}$ is high the costs of revealing himself as type ' $m$ ' are sufficiently high to compensate for the choice of an inefficient project rather than cash transfers. Instead, if $\lambda_{M}^{I}$ is low, a type " $M$ " incumbent has very little to lose by revealing himself. Thus this incumbent may as well choose to implement the project only if it is efficient, i.e. $\theta=\theta_{\mathrm{H}}$ and make direct cash transfers otherwise.

In summary, public projects generating public employment are preferred to cash transfers when a politician is particularly committed to redistribute in favor of a minority, but cannot afford to displease the group of voters which hold the balance of power. The two groups, which we labelled "majority" and "minority" can have an income-based or a racially based definition. That is we can think of "disguised" redistributions from the middle class to the poor and/or across racial divides. In the empirical sections which follow we establish that public eraployment in US cities appear to respond to different degrees of income inequality and racial composition of the electorate. These results are consistent with a use of pullic employment as a disguised redistributive device.

\section{Data}

We study public employment in all US cities with a population larger than 25,000 . All the right-hand-side variables used in the paper are listed in Table 1; all of them, except government employment are taken from Alesina, Baqir and Easterly (1996). The original source of the data and the source for government employment data is the City and County Databook, which reflects information gathered in the 1990 Population Census and the 1992 Census of Governments. The inequality and income data refer to 1990; the demographic variables refer to 1990; and the 
government employment data refer to 1991.

Since we are particularly interested in the effects of income inequality on public employment, we use four measures of income distribution: a Gini coefficient, the ratio of mean to median household income and the percent of families and percent of individuals below the poverty level. ${ }^{8}$ These measures capture well our priors about which cities are unequal or contain large poor populations. The city with the highest Gini (i.e. highest inequality) is Miami Beach, Florida. The city with the lowest Gini is Bowie, Maryland, a homogeneous middle-class suburb of Washington DC. Beverly Hills CA has the highest mean to median ratio (with Miami Beach 2nd); the lowest mean to median ratios are in small Midwestern towns. The highest poverty rate towns are in the South; the lowest poverty rate is in the already-mentioned Bovrie, Maryland. The hypothesis we test with this data is that higher inequality increases the demand for redistribution, which due to the arguments developed in the theory section takes the dis:zuised form of higher public employment.

Our measure of racial diversity is the variable ETHNIC, an index of ethnic fractionalization. This variable measures the probability that two randoinly drawn individuals from the population belong to two different ethnic groups. Specifically we consider the population distribution by race used by the US Census and we construct ETHNIC as follows:

$$
\text { ETHNIC }=1-\sum_{i}\left(\text { Race }_{i}\right)^{2}
$$

${ }^{8}$ Note that the mean to median income is the critical measure of inequality in models of redistributive policies where the median voter is decisive, like in Meltzer and Richards (1981) 
where Race, is the share of population self identified as of race $i$ and

$$
i=\{\text { White, Black, Asian and Pacific Islander, American Indians, Other }\}
$$

This is the same variable which we used in Alesina, Baqir and Easterly (1996). In that paper we noted that Hispanic is not a mutually exclusive category in these racial classifications. Hispanic is reported as an answer to a different question concerning origin. However, there is an almost perfect correlation between Hispanic and "Other" in the sample: the correlation is 0.9 . Probably the reason is that individuals of Hispanic origins did not feel adequately characterized by the available racial choices, and they answered "other" to the question aiout race. Therefore, for practical purposes, the category "other" is essentially identical to "Hispanic". The variable ETHNIC varies considerably across cities. The minimum value occurs in Gloucester, Mass. (0.014), the maximum in Carson, $\mathrm{Ca} .(0.73)$. The hypothesis is that more ethnic fragmentation leads to racially determined political conflicts, and public employment is a way of favoring one (racially determined) group or the other.

We measure government employment per 1000 of the total population and per 1000 of the working age population (18-64). As Table 2 shows this variable has a very large range. The lowest government employment per 1000 population is 0.50 in Highland CA. The highest local government employment is 86.9 in Jackson $\mathrm{TN}^{9}$ and the second is Washington D.C. with 76.8 The average is about 13 .

Table 3 displays the basic correlations between variables. Focusing in particular on the first two lines, one notes a rather high positive correlation between all the indices of inequality and our two measures of public employment, implying that higher inequality is associated with larger

\footnotetext{
${ }^{9}$ See below for a discussion of this data point.
} 
city employment. The highest correlation is with the GINI index. The cu l elation between Ethnic and Government employment is much lower, although with the expected sign. Government employment has a positive correlation with unemployment, indicating that public employment may be used as corrective measure for labor market imperfections. Public employment is also positively associated with the share of the elderly, since the latter require a larger amount of health and welfare services.

Note that the measures of income inequality which we use are highly correlated with each other, but the correlation is far from perfect. For instance the Gini coefficient has a correlation of about $0.7-0.8$ with poverty ratios, while the mean to median ratio has a correlation of $0.5-0.6$ with the poverty ratio. Thus the different measures seem to pick up somewhat different aspects of inequality. The variable ETHNIC is positively correlated with all the messures of inequality, but the correlation is not overwhelmingly high (between 0.24 and 0.5 dependirig on the measure). Not surprisingly, poverty ratios are positively correlated with unemployment.

Figure 1 highlights the positive simple correlation between the Gini index of income inequality and city government employment. The picture displays city government employment and the value of the Gini for 10 successive deciles of the Gini from the lowest (least inequality) to the highest (most inequality). City government employment is monotonically increasing with the Gini, except for a small statistically insignificant dip between the ninth and tenth decile. The standard error bands (dotted lines in figure 1) make clear that the increase in government employment with the Gini over the full range is significant.

\section{Regression Results}


Table 4 presents several regressions in which the dependent variable is city public employment per capita. We have eight regressions, two for each of our four measures of income inequality. The first regression of each pair includes only the inequality variable. The second regression of each pair includes several control variables: percent of the population with a college degree or higher, ethnic diversity, income per capita, log of population, share of the population above 65 , and the unemployment rate. In addition to the right hand side variables explicitly displayed we also have included state dummy variables, which are not displayed. State dummies may capture all sorts of geographical, ideological and regional effects not included in the other right hand side variables.

In all the regressions the coefficient on the income inequality variable is highly significant, and with the predicted sign: more inequality is associated with larger public employment. The $t$ statistics on the inequality variables vary from 3.8 to more than 11 . The size of the coefficient is also non trivial: in column 2 in Table 4 an increase of 1 standard deviation in the Gini (increase of .054) would be associated with an increase of about one-fith of a standard deviation in government employment (increase of 1.75 employees per thousand popuation). Since the maximum conceivable variation of the Gini is between zero and one, the coefficient on the Gini measures the change in government employment associated with a movement from perfect equality to perfect inequality -- 32 more employees per thousand population.

The coefficient on ethnic diversity is also significant in all four regressions with different measures of inequality and poverty. Cities that are more racially diverse have more government employment per capita. A one standard deviation increase in ETHNIC will raise government employment by a tenth of a standard deviation (calculated from regression 2 in Table 4). A 
movement from complete homogeneity $(\mathrm{ETHNIC}=0)$ to complete het $\mathrm{t}$ ) geneity $(\mathrm{ETHNIC}=1)$ would raise government employment by the amount of the coefficient on ETHNIC -- 5.4 more employees per thousand.

Of the other controls, the only ones that are significant are the shate of population over 65 and the size of population. The coefficient on the age structure is always significant (with one exception): older populations require more public services for health and welfare. ${ }^{10}$ The coefficient on the log of population is significantly positive. On the one hand one may argue that there might be economies of scale in government size, so one should expect a negative sign on this coefficient. ${ }^{11}$ On the other hand larger cities may be associated with more difficult public policy problems requiring more social services.

\section{Sensitivity of the results}

Our first robustness check is to omit the state dummies (Table 5). First of all, all the income inequality measure remain strongly significant, with $t$ statistics varying from 3.5 to more than 12 . Note that the first regression, with only the constant and the GivI coefficient has an $\mathrm{R}^{2}$ of 0.12 , which is quite high for a sample of this size and so few control variables.

The coefficient on ethnic diversity is positive and statistically significant in all the regressions with state dummies, but loses significance without state dummies. Some analysis

${ }^{10}$ Note that school teachers are typically county rather than city einployees; thus schoolteachers are not the reason behind the age structure effect. Moreover, we tried an age structure variable measuring the ratio of 5 to 17 year olds to population and found it to be generally insignificant; it leaves results on the other variables unchanged.

${ }^{11}$ For some results on economies of scale in the size of government in a cross country sample see Alesina and Wacziarg (1998) 
reveals the sources of these results. First, California is a state with high $\Sigma i$ inic fragmentation and low public employment. Second, New England (a relatively "liberal" region) has low ethnic fragmentation and high public employment. When we control for these state-specific characteristics, we find a significant positive relationship between ethnic diversity and city government employment.

The results on age structure and population remain significant when state dummies are not included. However, the results on some of the other controls change depending on whether state dummies are included.Unemployment is strongly significant without state dummies, while it was insignificant with state dummies. It is plausible that public employment is used to compensate for slack private labor markets. The coefficient on college education is sometimes significant suggesting some weak evidence that more educated populations may demand a richer bundle of public goods, such as parks, libraries, publicly supported cultural projects, etc. Finally, income per capita is not correlated with city employment, regardless of whether state dummies are included or not.

We have also checked whether our results change when we use as dependent variable not public employment per capita but public employment per working age population (18 to 64 years of age). The results on the effect of income inequality on public employment are unaffected. ${ }^{12}$

Next we checked for the effect of outliers, the presence of which may be indicated by the wide range of the public employment data. Figure 2 plots the partial scater of the Gini coefficient versus government employment. That is, we plot the component of government employment that

${ }^{12}$ Some of the coefficients on the other controls are different with this alternative dependent variable. Details are available upon request. 
is orthogonal to all the right hand side variable except for the Gini agains: the component of the Gini that is orthogonal to these same right hand side variables. This plot dentifies the positive correlation between the Gini coefficient and public employment and clearly highlights three outliers, Beverly Hills, North Chicago and Jackson TN. Jackson TN was already mentioned above as the city with the highest ratio of public employees over the population (86.9), but it has little effect on the slope because it is in the middle of the sample on the Gini. ${ }^{i j}$ Beverly Hills and North Chicago have unusually high inequality, but tend to cancel each other out with government employment -- Beverly Hills being above the line and North Chicago below the line. All our results are robust to dropping these three outliers, one at a time or together. The same holds when we repeat the same analysis with all the other measures of income inequality. More generally, we excluded the extreme values of the Gini coefficient that were more than iwo standard deviations away from the mean for the Gini coefficient (this results in 57 observations being excluded). Inequality and ethnic fragmentation remain significant in this truncated sćmple. ${ }^{14}$

We have also explored in more detail the issue of racial fragmentation, by checking whether our results are robust to different measures of ethnic diversity. is, of course, "black", which is one of the components of ETHNIC. The variables "black" and ETHNIC, are positively correlated (0.5) but are far from identical. In Table 6 we investigate the difference between using "black" and "ETHNIC" as our measure of the racial mix. The

${ }^{13}$ We have actually called the city government of Jackson, Tenntssee and spoken to the personnel director to try to find the explanation for their high employmert. She was not aware of having such disproportionate public employment. We suspect a reporting error. Dropping Jackson from the sample does not change the results. The results on income inequality are unaffected, while the coefficient on ethnic has a slightly lower $\mathrm{t}$-statistic but remains highly significant.

${ }^{14}$ All these results are available upon request. 
regressions include state dummies. Both "black" and "ETHNIC" are $\mathrm{si}_{\xi}$ '; ficant when either is inserted as a measure of ethnic composition of the population. All four inequality measures remain significant, regardless of which variable for the racial composition is used.

We also ran this experiment without state dummies (not shown, results available upon request.). As we already noted, the variable ETHNIC is not significant without state dummies. But the variable "black" is significant, even without state dummies. As for the inequality measures in the regressions without state dummies, the Gini coefficient is always significant while the poverty ratios lose statistical significance in the regressions with "Black" rather than ETHNIC. The lack of significance of the poverty ratios with Black is due to the high positive correlation between Black and poverty ratios, higher than the correlation between ETHNIC and poverty ratios. The correlation between Black and the family poverty rate is .58 . nile the correlation between Ethnic and the family poverty rate is .48 .

Next, we explore the correlation between our measure of inequality and other determinants of city employments. In Table 7 we present several regressions, with and without our measures of inequality. ${ }^{15}$ Let's look first at the equation with the Gini coefficient as a measure of inequality. The interesting observation is that virtually all the other control variables -proportion of college graduates, ethnic diversity, population 65 and up, and the unemployment rate -- increase considerably in absolute value and statistical significance in the regression without the measure of inequality. All of the listed variables, except ethnic diversity, lose significance when the inequality measure enters the equation. This pattern generally holds with every measure

${ }^{15}$ This table includes state dummies, but analogous results on this point are obtained without state dummies. 
of inequality. An interpretation of this finding is that income inequality is strongly correlated with some of the other controls, and their effect on public employment is overestimated when the variable for income inequality is not included in the regression. In fact, i1 we go back to Table 3 , we note that many of the correlations between the various measures of inequality and other right hand side variables are quite large, in absolute value. For instance, the Gini coefficient has a correlation of almost 0.4 with the share of the population above 65 ; the family poverty ratio has a correlation of more than 0.5 with the unemployment rate; the family poverty ratio has a correlation of .5 with Ethnic diversity; the ratio of mean to median income has a correlation of .24 with proportion of college graduates.

Finally we have also explored data on the composition of public employment, by looking at different categories: central administration, streets and highways, housing and community development, libraries, natural resources, parks and recreation, welfare, :ewerage, and solid waste management. ${ }^{16}$ The results (available upon request) show that the effect of income inequality and ethnic fragmentation on public employment apply to virtually all these categories, and there is no intelligible pattern favoring one component or the other. In particular, income inequality and ethnic fractionalization affect employment also in sectors which may apếér "productive" (parks, solid waste management, etc.). However, this is consistent with the theoretical model: in fact, according to the theory, politicians would want to "hide" redistributive policies in programs which may appear (on paper) to be chosen purely for productive efficiency.

\footnotetext{
${ }^{16}$ The source for the sectoral composition of government employment is the same as for total government employment: the 1992 Census of Governments.
} 


\section{Conclusions}

We have provided theoretical and empirical support for the notion that politicians disguise their redistributive policies in the form of public employment, in order tu avoid opposition to explicit tax-transfer schemes. We document that in American cities pulic employment is higher in cities that have more income inequality, controlling for other economic and demographic determinants of public employment. We also show that public employment is higher in cities that are more ethnically fragmented, suggesting that disguised redistributive policies may have a racial dimension as well. 


\section{References}

Alesina, A., R. Baqir and W. Easterly (1996): "Public Goods and Ethnic Divisions." NBER Working Paper.

Alesina, A. and D. Rodrik (1994) "Distributive Politics and Economic (in owth." Quarterly Journal of Economics, 465-90.

Alesina, A. and H. Rosenthal (1995): Partisan Politics, Divided Government and the Economy, Cambridge University Press, Cambridge, UK.

Alesina, A. and R. Wacziarg (1998): "Openness, Country Size and the Government." Journal of Public Economics, Forthcoming..

Austen-Smith, D. and J. Banks (1989): "Electoral Accountability and Iricumbency." in Ordeshook, P. Models of Strategic Choice in Politics, University of Michigan Press, Ann Arbor, Mi.

Barro, R. (1973) “The Control of Politicians: An Economic Model.” Public Choice, 14, 19-42.

Coate, S. and S. Morris (1995): "On the Form of Transfers to Special Interests." Journal of Political Economy, 103, 1210-36.

Ferejohn, J. (1986): “Incumbent Performance and Electoral Control.” Public Choice, 5-25.

Grosh, Barbara, 1991, Public Enterprise in Kenya: What Works, What floesn't and Why, Boulder: Lynne Rienner Publishers ;

Meltzer, A. and S. Richards (1981): "A Rational Theory of the Size of C jvernment."Journal of Political Economy, 81, 914-27.

Miller, Norman and Rodger Yeager, 1994, Kenya: the Quest for Prosperity, Boulder: Westview

Perotti, R. (1996): "Democracy, Income Distribution and Growth: What the Data Say." Journal of Economic Growth, 7, 149-87.

Persson, T. and G. Tabellini (1994): "Is Inequality Harmful for Growth?" American Economic Review, March.

Rodriguez, F. (1997a): “Does Inequality Lead to Redistribution?” Harvard University, unpublished. 
Rodriguez, F. (1997b): "Inequality, Redistribution and Rent Seeking." Harvard University, unpublished.

Tullock, G. (1983): Economics of Income Redistribution, Kluwer-Nighoff, Boston, Ma.

World Government Directory 
Figure 1: The Gini and Government Employment

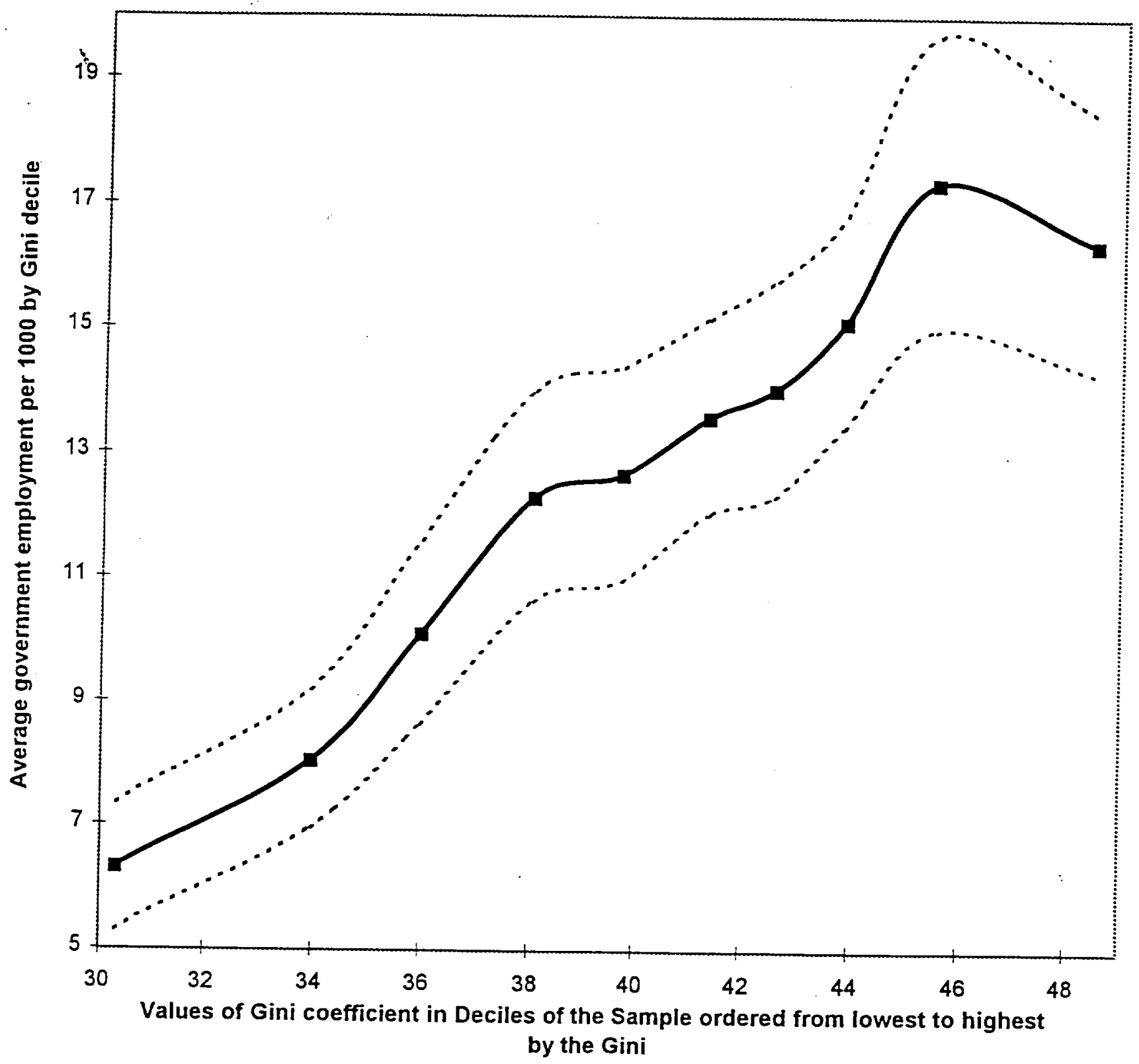




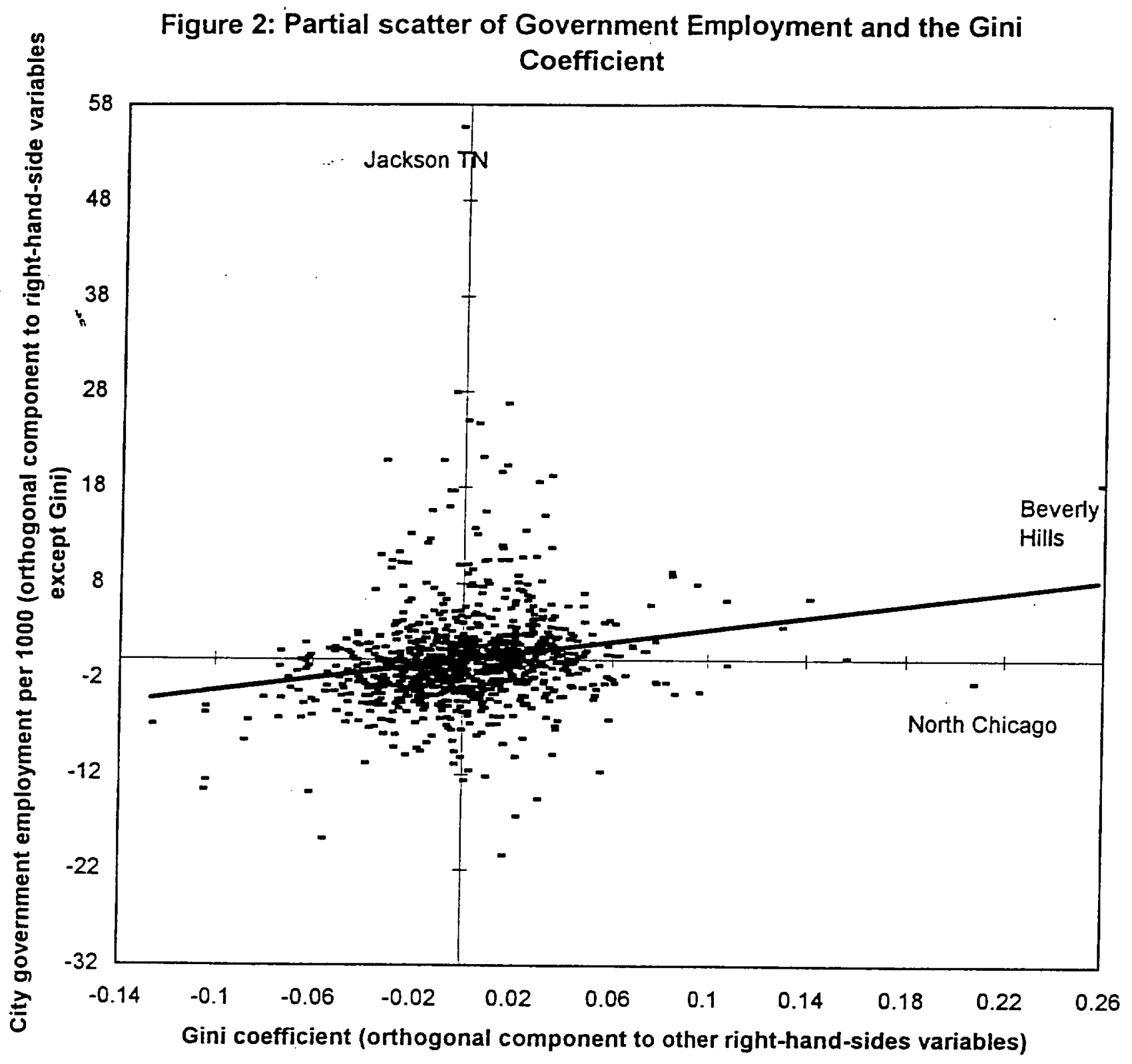


Table 1: Variable Definitions

\begin{tabular}{|c|c|c|c|}
\hline Variable & Description & Year & Source \\
\hline Govempl & City government employment per 1,000 population & 1991 & $\mathrm{CCD}$ \\
\hline Govemplw & $\begin{array}{l}\text { City government employment per 1,000 working age population (ages: 18- } \\
64 \text { ). Constructed from Govempl and population-by-age data. }\end{array}$ & 1991 & $\mathrm{CCD}$ \\
\hline Povertyp & Percent of persons with income below poverty level & 1989 & $\mathrm{CCD}$ \\
\hline Povertyf & Percent of families with income below poverty level & & $\mathrm{CCD}$ \\
\hline Gini & $\begin{array}{l}\text { Gini coefficient for income inequality. Constructed from population-by- } \\
\text { income data }\end{array}$ & 1989 & $\mathrm{CCD}$ \\
\hline Mean/Median & Ratio of mean to median household income & 1989 & $\mathrm{CCD}$ \\
\hline Ethnic & $\begin{array}{l}\text { Index of ethnic fractionalization. Measures the probability that two } \\
\text { randomly drawn people from a city will belong to different ethnic groups. } \\
\text { Constructed from population-by-race data. }\end{array}$ & 1990 & $\mathrm{CCD}$ \\
\hline Bagrad & Fraction of the $25+$ year-old population with a BA or higher degree & 1990 & $\mathrm{CCD}$ \\
\hline Unemplrt & Civilian labour force unemployment rate & 1991 & $\mathrm{CCD}$ \\
\hline Incomepc & Money income per capita, in $\$ 1,000$ s & 1989 & $\mathrm{CCD}$ \\
\hline Lpop90 & Log of city population & 1990 & $\mathrm{CCD}$ \\
\hline Pop65up & Fraction of population aged 65 or older & 1990 & $\mathrm{CCD}$ \\
\hline
\end{tabular}


Table 2: Summary Statistics

\begin{tabular}{|c|c|c|c|c|c|c|}
\hline Variable & Mean & Median & Minimum & Maximum & $\begin{array}{l}\text { Standard } \\
\text { Deviation }\end{array}$ & $\begin{array}{c}\text { No. of } \\
\text { Observations }\end{array}$ \\
\hline & & $\cdots$ & & & & \\
\hline Govempl & 12.55 & 9.90 & 0.50 & 86.90 & 9.03 & 1009 \\
\hline Govemplw & 19.08 & 15.62 & 0.75 & 146.10 & 13.03 & 1011 \\
\hline Gini & 0.40 & 0.41 & 0.23 & 0.57 & 0.05 & 1069 \\
\hline Mean/Median & 1.26 & 1.24 & 1.03 & 2.25 & 0.14 & 1076 \\
\hline Povertyp & 13.22 & 12.40 & 1.10 & 46.10 & 8.14 & 1076 \\
\hline Povertyf & 9.86 & 8.90 & 0.50 & 40.40 & 6.50 & 1076 \\
\hline Ethnic & 0.29 & 0.28 & 0.01 & 0.76 & 0.18 & 1076 \\
\hline Incomepc & 14.86 & 13.68 & 5.56 & 55.46 & 5.00 & 1076 \\
\hline Bagrad & 0.23 & 0.20 & 0.02 & 0.71 & 0.12 & 1076 \\
\hline Lpop90 & 10.97 & 10.76 & 10.13 & 15.81 & 0.77 & 1076 \\
\hline Unemplrt & 6.80 & 6.20 & 0.80 & 17.90 & 2.74 & 1027 \\
\hline Pop65Up & 0.12 & 0.12 & 0.02 & 0.49 & 0.05 & 1076 \\
\hline
\end{tabular}


Table 4: Regressions for City Govt. Employment per Capita (Controlling for State Dummies)

(1) (2)

(3)
(4)
(5)

(6)

(7)

(8)

Dependent Variable Govempl Governpl Govempl Govempl Govempl Govempl Govempl Govermpl Inequality Measure Gini Gini Mean/Median Mean/Median Povertyf Povertyf Povertyp Povertyp

\begin{tabular}{|c|c|c|c|c|c|c|c|c|}
\hline Constant & -7.712 & -21.603 & -6.684 & -20.516 & 7.620 & -14.195 & 7.187 & -15.252 \\
\hline 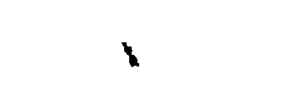 & -2.603 & 4.739 & -2.069 & -4.389 & 0.297 & -3.414 & 3.522 & -3.640 \\
\hline \multirow[t]{2}{*}{ Inequality } & 42.381 & 31.952 & 13.114 & 7.540 & 0.296 & 0.324 & 0.230 & 0.235 \\
\hline & 11.116 & 6.129 & 8.230 & 3.833 & 7.925 & 5.653 & 8.407 & 5.735 \\
\hline \multirow[t]{2}{*}{ Bagrad } & & 1.763 & & 5.105 & & 8.067 & & 2.173 \\
\hline & & 0.593 & & 1.655 & & 3.280 & & 0.722 \\
\hline \multirow[t]{2}{*}{ Ethric } & & 5.396 & & 5.930 & & 3.602 & & 4.858 \\
\hline & & 2.960 & & 3.286 & & 2.015 & & 2.758 \\
\hline \multirow[t]{2}{*}{ Incomepc } & & 0.126 & & -0.031 & & 0.105 & & 0.214 \\
\hline & & 1.619 & & -0.437 & & 1.308 & & 2.415 \\
\hline \multirow[t]{2}{*}{ Lpop90 } & & 1.334 & & 1.571 & & 1.463 & & 1.536 \\
\hline & & 3.788 & & 4.507 & & 4.146 & & 4.395 \\
\hline \multirow[t]{2}{*}{ Pop65Up } & & 7.906 & & 17.601 & & 19.858 & & 18.354 \\
\hline & & 1.476 & & 3.411 & & 4.321 & & 3.916 \\
\hline \multirow[t]{2}{*}{ Unemplrt } & & 0.136 & & 0.183 & & -0.025 & & 0.046 \\
\hline & & 1.376 & & 1.812 & & -0.232 & & 0.436 \\
\hline No. of observations & 1003 & 964 & 1010 & 971 & 1010 & 971 & 1010 & 971 \\
\hline Adjusted R-squared & 0.66 & 0.68 & 0.64 & 0.67 & 0.65 & 0.68 & 0.65 & 0.68 \\
\hline
\end{tabular}

Heteroskedasticity-corrected t-statistics are reported below coefficient estimates. 
Table 5: Regressions for City Government Employment per Capita (not controlling for state dummies)

\begin{tabular}{|c|c|c|c|c|c|c|c|c|}
\hline \multirow{3}{*}{$\begin{array}{l}\text { Dependent Variable } \\
\text { Inequality Measure }\end{array}$} & (1) & (2) & (3) & (4) & (5) & (6) & (7) & (8) \\
\hline & Govempl & Govempl & \multirow{2}{*}{$\begin{array}{c}\text { Govempl } \\
\text { Mean/Median }\end{array}$} & \multirow{2}{*}{$\begin{array}{c}\text { Govempl } \\
\text { Mean/Median }\end{array}$} & \multirow{2}{*}{$\begin{array}{l}\text { Govempl } \\
\text { Povertyf }\end{array}$} & \multirow{2}{*}{$\begin{array}{l}\text { Govempl } \\
\text { Povertyf }\end{array}$} & \multirow{2}{*}{$\begin{array}{l}\text { Govempl } \\
\text { Povertyp }\end{array}$} & \multirow{2}{*}{$\begin{array}{l}\text { Govemp } \\
\text { Povertyp }\end{array}$} \\
\hline & Gini & Gini & & & & & & \\
\hline \multirow{2}{*}{ Constant } & -10.548 & -35.370 & -7.433 & -31.491 & 9.036 & -25.067 & 9.079 & -25.735 \\
\hline & -5.987 & -5.689 & -2.923 & -4.899 & 20.063 & -4.191 & 19.585 & -4.303 \\
\hline \multirow[t]{2}{*}{ Inequality } & 57.736 & 47.700 & 15.800 & 8.071 & 0.354 & 0.291 & 0.261 & 0.176 \\
\hline & 12.464 & 7.432 & 7.706 & 3.650 & 7.720 & 4.142 & 7.640 & 3.378 \\
\hline \multirow[t]{2}{*}{ Bagrad } & & 3.673 & & 11.471 & & 15.046 & & 11.738 \\
\hline & & 0.973 & & 2.938 & & 4.483 & & 2.919 \\
\hline \multirow[t]{2}{*}{ Ethnic } & & -1.325 & & 0.296 & & -0.978 & & 0.022 \\
\hline & & -0.702 & & 0.154 & & -0.518 & & 0.012 \\
\hline \multirow[t]{2}{*}{ Incomepc } & & 0.151 & & -0.125 & & 0.016 & & 0.029 \\
\hline & & 1.941 & & -1.839 & & 0.192 & & 0.306 \\
\hline \multirow[t]{2}{*}{ Lpop90 } & & 1.851 & & 2.227 & & 2.120 & & 2.214 \\
\hline & & 3.754 & & 4.494 & & 4.232 & & 4.430 \\
\hline \multirow[t]{2}{*}{ Pop65Up } & & 15.733 & & 33.484 & & 37.597 & & 37.710 \\
\hline & & 2.126 & & 4.556 & & 5.750 & & 5.471 \\
\hline \multirow[t]{2}{*}{ Unemplrt } & & 0.569 & & 0.638 & & 0.495 & & 0.558 \\
\hline & & 4.096 & & 4.552 & & 3.318 & & 3.751 \\
\hline No. of observations & 1003 & 964 & 1010 & 971 & 1010 & 971 & 1010 & 971 \\
\hline Adjusted R-squared & 0.12 & 0.17 & 0.06 & 0.14 & 0.06 & 0.15 & 0.05 & 0.14 \\
\hline
\end{tabular}

Heteroskedasticity-corrected t-statistics are reported below coefficient estimates. 


\begin{tabular}{|c|c|c|c|c|c|c|c|c|}
\hline Black or ethnic & Black & Ethnic & Black & Ethnic & Black & Ethnic & Black & Ethnic \\
\hline Inequality measure & Gini & Gini & Mean/median & Mean/median & Povertyf & Povertyf & Povertyp & Povertyp \\
\hline Bagrad & 2.90 & 1.76 & 6.61 & 5.10 & 8.88 & 8.07 & 3.76 & 2.17 \\
\hline t-stat & 0.96 & 0.59 & 2.08 & 1.65 & 3.56 & 3.28 & 1.21 & 0.72 \\
\hline Black or ethnic & 8.19 & 5.40 & 7.64 & 5.93 & 4.76 & 3.60 & 6.09 & 4.86 \\
\hline t-stat & 3.37 & 2.96 & 3.41 & 3.29 & 2.04 & 2.02 & 2.68 & 2.76 \\
\hline Incomepc & 0.09 & 0.13 & -0.07 & -0.03 & 0.07 & 0.11 & 0.16 & 0.21 \\
\hline t-stat & 1.08 & 1.62 & -0.95 & $-0 .+4$ & 0.84 & 1.31 & 1.68 & 2.41 \\
\hline Lpop90 & 1.32 & 1.33 & 1.62 & 1.57 & 1.51 & 1.46 & 1.60 & 1.54 \\
\hline t-stat & 3.66 & 3.79 & 4.63 & 4.51 & 4.24 & 4.15 & 4.53 & 4.39 \\
\hline Pop65up & 7.62 & 7.91 & 17.27 & 17.60 & 19.55 & 19.86 & 18.05 & 18.35 \\
\hline t-stat & 1.42 & 1.48 & 3.30 & 3.41 & 4.26 & 4.32 & 3.81 & 3.92 \\
\hline Unemplrt & 0.12 & 0.14 & 0.17 & 0.18 & -0.01 & -0.03 & 0.06 & 0.05 \\
\hline t-stat & 1.15 & 1.38 & 1.68 & 1.81 & -0.11 & -0.23 & 0.52 & 0.44 \\
\hline Inequality & 30.17 & 31.95 & 6.78 & 7.54 & 0.30 & 0.32 & 0.21 & 0.23 \\
\hline t-stat & 5.59 & 6.13 & 3.31 & 3.83 & 5.05 & 5.65 & 4.90 & 5.74 \\
\hline No. of observations & 964 & 964 & 971 & 971 & 971 & 971 & 971 & 971 \\
\hline Adjusted R-squared & 0.69 & 0.68 & 0.68 & 0.67 & 0.68 & 0.68 & 0.68 & 0.68 \\
\hline
\end{tabular}


table $w$ and wo ineq state dum

Table 7: Regressions for city government employment with and without inequality measure (controlling for state dummies)

\begin{tabular}{|c|c|c|c|c|c|c|c|c|}
\hline Dependent Variable & Govempl & Govempl & Govempl & Govempl & Govempl & Govempl & Govempl & Govempl \\
\hline Inequality Measure & Gini & Gini & Mean/Median & Mean/Median & Povertyf & Povertyf & Povertyp & Povertyp \\
\hline Bagrad & 1.76 & 11.54 & 5.10 & 11.54 & 8.07 & 11.54 & 2.17 & 11.54 \\
\hline t-stat & 0.59 & 4.57 & 1.65 & 4.57 & 3.28 & 4.57 & 0.72 & 4.57 \\
\hline Ethnic & 5.40 & 7.42 & 5.93 & 7.42 & 3.60 & 7.42 & 4.86 & 7.42 \\
\hline t-stat & 2.96 & 4.02 & 3.29 & 4.02 & 2.02 & 4.02 & 2.76 & 4.02 \\
\hline Incomepc & 0.13 & -0.08 & -0.03 & -0.08 & 0.11 & -0.08 & 0.21 & -0.08 \\
\hline t-stat & 1.62 & -0.92 & -0.44 & -0.92 & 1.31 & -0.92 & 2.41 & -0.92 \\
\hline Lpop90 & 1.33 & 1.64 & 1.57 & 1.64 & 1.46 & 1.64 & 1.54 & 1.64 \\
\hline t-stat & 3.79 & 4.68 & 4.51 & 4.68 & 4.15 & 4.68 & 4.39 & 4.68 \\
\hline Pop65up & 7.91 & 26.15 & 17.60 & 26.15 & 19.86 & 26.15 & 18.35 & 26.15 \\
\hline t-stat & 1.48 & 5.43 & 3.41 & 5.43 & 4.32 & 5.43 & 3.92 & 5.43 \\
\hline Unemplrt & 0.14 & 0.29 & 0.18 & 0.29 & -0.03 & 0.29 & 0.05 & 0.29 \\
\hline t-stat & 1.38 & 2.75 & 1.81 & 2.75 & -0.23 & 2.75 & 0.44 & 2.75 \\
\hline Inequality & 31.95 & & 7.54 & & 0.32 & & 0.23 & \\
\hline t-stat & 6.13 & & 3.83 & & 5.65 & & 5.74 & \\
\hline No. of observations & 964 & 971 & 971 & 971 & 971 & 971 & 971 & 971 \\
\hline $\mathrm{R} 2$ & 0.68 & 0.67 & 0.67 & 0.67 & 0.68 & 0.67 & 0.68 & 0.67 \\
\hline
\end{tabular}

